\title{
PENGARUH COUPLE PRENATAL CLASS TERHADAP KECEMASAN IBU DALAM MENGHADAPI PERSALINAN DI KLINIK HANA JOGONALAN KLATEN
}

\author{
Anik Kurniawati ${ }^{1}$ Endang Suwanti ${ }^{2}$ \\ Poltekkes Kemenkes Surakarta Jurusan Kebidanan
}

\begin{abstract}
Background: The husband is a wife's assistant and often as a decision maker both during pregnancy and childbirth, therefore the husband also needs to get the same information as pregnant women. According to Lutfiatus Sholihah (2004), during pregnancy, the husband must also be invited to prepare to welcome the arrival of the child, because not all husbands are ready to mentally wait for his wife who is in pain, sometimes they even panic and can not calm the wife who was giving birth.Based on a preliminary study conducted that the class of pregnant women is only given to mothers without involving the husband or partner. Preliminary study data also shows that there are still many pregnant women who come to health workers during the fake labor phase. Pregnant women arrive early due to anxiety and fear of facing labor. The purpose of this study was to determine the effect of prenatal class couples on maternal anxiety in facing labor at the Hana Jogonalan Klaten clinic. Methods: This type of research is Quasi experiment, with post test design without control group design. The study was conducted at the Klaten Jogna Hanna clinic from May to August 2018. The target population in this study were pregnant women with a minimum gestational age of 36 weeks with a total population of 20 respondents. The sampling technique in this study was total sampling. 10 respondents were given classes of pregnant women with husband's assistance and 10 respondents were given classes of ordinary pregnant women, classes of pregnant women were given 2 times in 1 month. Result: The respondent's anxiety state was measured using the Hamilton Rating Scale For Anxiety (HRSA) research instrument. Data analysis was performed by univariate and bivariate analysis using the Spearman Rank test. Conclusion: Showed there was no effect of couple prenatal class on maternal anxiety with a p value of 0.193 and a correlation coefficient of 0.302 .
\end{abstract}

Keywords: Couple Prenatal Class, Anxiety, Childbirth

\section{PENDAHULUAN}

Pemerintah Indonesia telah berkomitmen untuk memperbaiki kesehatan maternal dan neonatal melalui berbagai upaya dan program, salah satu program adalah Suistanable Development Goals (SDGs) yang merupakan kelanjutan dari program Millenium Development Goals (MDGs). Target SDGs untuk kesehatan maternal neonatal di tahun 2030 adalah menurunkan angka kematian ibu sebesar 70/100.000 kelahiran hidup, angka 
kematian neonatal 12 per 1000 dan angka kematian balita menjadi 25 per 1000 , sedangkan di Jawa Tengah sendiri Angka Kematian Ibu sebesar 126, 55 per 100.000 kelahiran hidup sedangkan angka kematian neonatal sebesar 7,2 per 1000 kelahiran hidup di tahun 2015 (SDKI, 2015)

Kematian ibu dapat terjadi pada masa kehamilan, persalinan atau masa nifas. Pada dasarnya persalinan adalah proses fisiologis yaitu proses dimana seorang wanita melahirkan bayi yang diawali dengan kontraksi uterus yang teratur dan memuncak pada saat pengeluaran bayi sampai dengan pengeluaran plasenta dan selaputnya dimana proses persalinan ini akan berlangsung selama 12 sampai 14 jam (Mayles, 1996).

Persalinan adalah hal yang normal dan alami, akan tetapi bisa menjadi patologis apabila ibu bersalin dan tenaga kesehatan kurang memahami tentang proses kehamilan dan persalinan, demikian juga pasangan atau suami ibu hamil. Fenomena yang terjadi pada ibu hamil menjelag persalinan saat ini adalah pada saat ibu hamil merasakan kontraksi uterus sebagai awal permulaan persalinan datang ke tenaga kesehatan atau bidan pada waktu yang kurang tepat untuk mendapatkan pertolongan persalinan, karena tanda tersebut merupakan tanda persalinan palsu.

Hal tersebut terjadi dikarenakan ibu merasa cemas dalam menghadapi persalinan, bahkan tidak jarang cemas tersebut akan berkelanjutan selama masa persalinan sehingga mengganggu keluarnya hormon oksitosin. Oksitosin adalah hormon pemicu munculnya kontraksi uterus. Apabila hormon oksitosin terhambat keluar maka akan mengakibatkan terjadinya kontraksi yang tidak adekuat.

Pemerintah sudah mengeluarkan program yang dapat digunakan untuk menyelesaikan permasalahan tersebut dengan kegiatan kelas ibu hamil (Depkes RI, 2009). Dalam buku pedoman kelas ibu hamil dikatakan bahwa kelas ibu hamil adalah kelompok belajar ibu hamil mulai usia 20 sampai 32 minggu dengan jumlah peserta minimal 10 orang. Materi yang disampaikan dalam kelas ibu hamil antara lain perubahan fisilogis kahamilan, persiapan persalinan, persalinan, nifas, perawatan bayi, KB dan mitos yang ada seputar kesehatan ibu dan anak. Kegiatan kelas ibu hamil dilakukan minimal 3 kali dengan pendampingan suami atau keluarga 1 kali. Suami adalah pendampingan istri dan seringkali sebagai pengambil keputusan baik saat kehamilan maupun persalinan, maka dari itu suami juga pelru mendapatkan informasi yang sama dengan ibu hamil. Menurut Lutfiatus Sholihah (2004), selama masa kehamilan, suami juga sudah harus diajak menyiapkan diri menyambut kedatangan si kecil, karena tidak semua suami siap mental menunggui istrinya yang sedang kesakitan, adakalanya mereka malah panik dan tidak bisa menenangkan istri yang sedang bersalin.

Berdasar studi pendahuluan yang dilakukan bahwa kelas ibu hamil hanya diberikan pada ibu tanpa melibatkan suami atau pasangan. Data Studi pendahuluan juga menunjukkan bahwa masih banyak ibu hamil yang datang ke tenaga kesehatan pada fase persalinan palsu.

Berdasarkan latar belakang tersebut maka peneliti tertarik untuk melakukan penelitian dengan judul pengaruh couple prenatal class terhadap kecemasan ibu 
B. Analisis Bivariat

Tabel 3. Kecemasan Ibu Dalam Menghadapi Persalinan

\begin{tabular}{|c|c|c|}
\hline Kecemasan & Jumlah & $\%$ \\
\hline Ringan & 11 & 55.0 \\
\hline Sedang & 9 & 45.0 \\
\hline Total & 20 & 100.0 \\
\hline
\end{tabular}

diatas responden dengan kecemasan ringan sebanyak 11 responden $(55 \%)$ dan responden dengan kecemasan sedang sebanyak 9 responden (45\%).

\section{Couple Prenatal Class}

Hasil penelitian couple prenatal class diperoleh hasil sebagai berikut:

Tabel 4. Kecemasan Couple Prenatal Class

Couple Prenatal Class Jumlah \%

Dengan Pendamping $\quad 10 \quad 50.0$

Tanpa Pendamping $\quad 10 \quad 50.0$

\begin{tabular}{lrr}
\hline Total & $\mathbf{2 0}$ & $\mathbf{1 0 0 . 0}$ \\
\hline
\end{tabular}

Berdasarkan hasil penelitian diatas diperoleh couple prenatal class diperoleh dengan pendamping sebanyak 10 responden (50\%) dan tanpa pendamping sebanyak 10 responden $(50 \%)$.

2. Pengaruh Couple Prenatal Class Terhadap Kecemasan Ibu Dalam Menghadapi Persalinan Di Klinik Hana Jogonalan Klaten.

Tabulasi silang couple prenatal class dan kecemasan ibu dalam menghadapi persalinan di Klinik Hana Jogonalan Klaten sebagai berikut:
Tabel 5. Pengaruh Couple Prenatal Class

Dan Kecemasan Ibu Dalam Menghadapi

Persalinan di Klinik Hana Jogonalan Klaten

\begin{tabular}{|c|c|c|c|c|c|c|}
\hline \multirow{3}{*}{$\begin{array}{l}\text { Couple } \\
\text { Prenatal } \\
\text { Class }\end{array}$} & \multicolumn{4}{|c|}{ Kecemasan } & \multirow{3}{*}{ ? } & \multirow{3}{*}{$\begin{array}{l}\text { Coefisie } \\
\text { corelasi }\end{array}$} \\
\hline & \multicolumn{2}{|c|}{ Ringan } & \multicolumn{2}{|c|}{ sedang } & & \\
\hline & $\mathbf{n}$ & $\%$ & $\mathbf{n}$ & $\%$ & & \\
\hline $\begin{array}{l}\text { Dengan } \\
\text { Pendamping }\end{array}$ & 7 & 35 & 3 & 15 & 0.196 & 0.3 \\
\hline $\begin{array}{l}\text { Tanpa } \\
\text { Pendamping }\end{array}$ & 4 & 20 & 6 & 30 & & \\
\hline Total & 11 & 55 & 9 & 45 & & \\
\hline
\end{tabular}

diatas menunjukkan responden terbesar pada Couple Prenatal Class dengan pendamping dengan kecemasan ringan sebanyak 7 responden (35\%) dan dengan pendampingan sebanyak 4 responden (20\%), sedangkan yang mengalami kecemasan sedang pada responden yang didampingi sebanyak 3 orang $(15 \%)$ dan yang tidak didampingi 6 orang $(30 \%)$.

Uji pengaruh couple prenatal class terhadap kecemasan ibu dalam menghadapi persalinan di Klinik Hana Jogonalan Klaten dengan menggunakan sperman rank diperoleh hasil sebagai berikut:

Berdasarkan hasil uji sperman rank diperoleh Correlation Coefficient sebesar $(0,302)$ dengan nilai sig $(0,196)>0,05$ H0: diterima dapat diartikan bahwa tidak terdapat pengaruh couple prenatal class terhadap kecemasan ibu dalam menghadapi persalinan di Klinik Hana Jogonalan Klaten.

\section{PEMBAHASAN}

Couple prenatal class bertujuan untuk melibatkan peran aktif suami atau pasangan dalam menghadapi kehamilan dan persalinan. Ibu hamil dan pasangannya mampu memahami fisiologi kehamilan, persiapan persalinan dan proses persalinan. Ibu hami dan 
pasangannya dapat membuat perencanaan persalinan sesuai dengan harapan. Upaya prenatal couple class dilakukan untuk membuat suami memahami proses kehamilan dan persalinan sehingga dapat meningkatkan peran dengan memberikan dukungan saat bersalin. Dukungan suami dan keluarga dapat mengurangi rasa cemas, karena keluhan ibu bersalin akan ditanggapi positif sehingga tercipta rasa tenang. Dengan mengikuti kelas kehamilan diharapakan suami dapat mengerti perannya pada masa persalinan antara lain dengan meberikan motivasi, maupun menenangkan selama proses persalinan (Mardjan, 2016).

Berdasarkan hasil uji sperman rank diperoleh Correlation Coefficient sebesar $(0,302)$ dengan nilai sig $(0,196)>0,05$ H0: diterima dapat diartikan bahwa tidak terdapat pengaruh couple prenatal class terhadap kecemasan ibu dalam menghadapi persalinan di Klinik Hana Jogonalan Klaten.

Hasil penelitian ini berbeda dengan teori Mardjan (2016), hal ini memungkinkan terjadi karena semua responden dalam penelitian ini berada pada rentang usia reproduktif. Sejalan dengan peneletian Alibahsyah (2017) yang mengatakan bahwa ibu dalam rentang usia antara 20-35 tahun memiliki tingkat kecemasan yang lebih ringan jika dibandingkan dengan ibu dalam rentang usia kurang dari 20 tahun atau lebih dari 35 tahun, hal ini juga didukung oleh penelitian Heriani (2016) yang mengatakan bahwa rentang usia 20-35 tahun kondisi fisik wanita dalam keadaan prima, rahim sudah mampu memberi perlindungan, mental pun siap untuk merawat dan menjaga kehamilannya secara hati-hati. Usia juga mempengaruhi kesiapan ibu dalam menerima kehamilannya serta dalam mempersiapkan persalinan

Selain dari faktor usia, pendidikan ibu juga merupakan salah satu faktor yang menentukan kecemasan ibu, hal ini sejalan dengan pendapat Hidayat (2004) bahwa pendidikan pada umumnya memiliki korelasi yang kuat dengan pengetahuan, dimana pengetahuan dimana tingkat pendiidkan yang tinggi akan membentuk pola adaptif terhadap kecemasan karena memiliki koping yang lebih baik. Hal yang sama juga didapatkan dari hasil penelitian sholichah (2015) bahwa pendidikan yang tinggi akan membuat seseorang banyak pengetahuannya dan makin mudah menerima proses informasi sehingga membuat ibu lebih tenang. Menurut Heriani (2016) bahwa semakin tinggi pendidikan seseorang maka akan semakin besar peluang untuk mencari pengobatan ke tenaga kesehatan. Sebaliknya, semakin rendahnya pendidikan seseorang akan menyebabkan seseorang mengalami stres, dimana stres dan kecemasan yang terjadi disebabkan kurang nya informasi yang didapat orang tersebut.

Responden dalam penelitian semua mengikuti kelas ibu hamil. Pelaksanaan kelas ibu bermanfaat dalam hal persiapan baik secara fisik maupun psikologis ibu dalam menghadapi persalinan. Dalam segi psikologis kegiatan ibu dapat meningkatkan kepercayaan diri yang cukup dalam menghadapi persalinan, dengan mengikuti kelas ibu, ibu hamil mempunyai pengetahuan, keterampilan serta motivasi terkait dengan kesadaran untuk meningkatkan kesehatan ibu dan bayi yang didapatkan selama mengikuti pelajaran pada kegiatan kelas hamil. Hal ini meningkatkan kesiapan mental ibu hamil dalam menghadapi persalinan 
sehingga akan tercipta keadaan yang tenang, santai, rileks dan nyaman dalam menghadapi persalinannya (Depkes, 2009).

Didukung pula dengan memiliki pendidikan minimal D3 dengan usia 20-35 tahun, sehingga berdasar teori dan hasil penelitian diatas mampu mengelola kecemasannya sendiri.

\section{KESIMPULAN DAN SARAN}

Kesimpulan:

1. Karakteristik Responden menunjukkan semua responden berada pada rentang usia reproduktif 20-35 tahun (100\%), dan tingkat pendidikan tinggi (45\%), tingkat pendidikan menengah $(55 \%)$.

2. Kecemasan ibu dalam menghadapi persalinan menunjukkan responden dengan kecemasan ringan sebanyak 11 responden $(55 \%)$ dan kecemasan sedang 9 responden $(45 \%)$.

3. Tidak terdapat pengaruh couple prenatal class terhadap kecemasan ibu dalam menghadapi persalinan di Klinik Hana Jogonalan Klaten ditunjukkan dengan Correlation Coefficient sebesar $(0,302)$ dengan nilai sig $(0,196)>0,05$.

Saran:

1. Ibu Hamil

Untuk ibu hamil, sebaiknya selalu m engikuti kelas ibu hamil yang sudah menjadi program pemerintah, baik sendiri maupun dengan pendampingan suami. Bagi ibu hamil dengan faktor risiko usia sebaiknya pelaksanaan kelas ibu hamil dengan melibatkan pasangannya

2. Tenaga Kesehatan

Tenaga kesehatan hendaknya rutin melakukan kelas ibu hamil sesuai dengan program pemerintah

\section{DAFTAR RUJUKAN}

Alibasjah dkk. 2016. Hubungan usia ibu hamil TM III dengan kecemasan menghadapi persalinan pada primigravida.journal.unwasgati.ac .id.

Ambar Dwi Erawati, 2011. Buku Ajar Asuhan Kebidanan Persalinan Normal. Jakarta; Buku Kedokteran EGC.

Aprillia. 2010. Hipnostetri Rileks, Nyaman, dan Aman Saat Hamil dan Melahirkan. Transmedia. Jakarta.

Cunningham, et.al. 2010. E-book Williams Obstetrics, edisi 23. The Mc Graw-Hill Companies,mUSA. Bobak. Tanda-Tanda persalinan.

Departemen Kesehatan RI. 2009. Pedoman Pelayanan Antenatal di Tingkat Pelayanan Dasar. Jakarta.

Hajar. 2012. Amani Birth Buku Pedoman Pengajar (alih Bahasa Oleh Amelita D. Surtikanti). USA. AMANI Inc Delaware.

Hawari, 2011, Manajemen Stress, Cemas dan Depresi. Jakarta. Fakultas Kedokteran Universitas Indonesia

Heriani. 2016. Kecemasan Menjelang Persalinan Ditinjau dari Paritas, Usia dan Tingkat Pendidikan. Journal Kesehatan Aisyiyah Pringsewu.

Kemenkes RI. 2016. Buku Kesehatan Ibu dan Anak. Kementerian Kesehatan Republik Indonesia dan JICA (Japan International Cooperation Agency).

Manuaba. Manuabaa Ida Ayu Candradinata. 2010. Ilmu Kebidanan Penyakit Kandungan dan KB Untuk Pendidikan Bidan Edisi 2. Jakarta; EGC. 
Mardjan, 2016. Pengaruh Kecemasan pada Kehamilan Primipara. Abrori Institute. Pontianak.

Mochtar. 2013. Synopsis Obstetri. Jakarta. EGC.

Prawiroharjo. 2014. Ilmu Kebidanan. Jakarta. PT Bina Pustaka.

Saifudin. Abdul Bari Saifudin. 2011. Buku Panduan Praktis Pelayanan Kesehatan Maternal Neonatal. Jakarta; PT Bina Pustaka Sarwono Prawirohardjo.

Sholichah.2015. Hubungan Tingkat Pendidkan Dengan Tingkat Kecemasan Wanita Usia 40-50 Tahun Dalam Menghadapi Monopouse. E-journal.akbidpurworejo.ac.id.

Susanti. Psikologi Kehamilan. EGC. Jakarta

Varney, Helen. 2007. Buku Ajar Asuhan Kebidanan Edisi 4 Volume 1. Jakarta;

Walsh. 2008. Buku Ajar Kebidanan Komunitas. Jakarta. EGC.

Wijayanti. 2016. Hubungan keikutsertaan ibu hamil dalam kelas Hamil Dengan Tingkat Kecemasan Menghadapi Persalinan Pada Ibu Hamil TM III Di Desa Karangmangu Sarang Kabupaten Rembang. Journal Ilmu Keperawatan dan Kebidanan (JIKK) Vol II No.5

Yainanik. 2017. Usia, Tingkat Pendidkan dan Pengetahuan ANC Primigravida Dalam Kecemasan Menghadapi Persalinan. eprints.ums.ac.id. 